\title{
Quaternary groundwater aquifer suitability for drinking in Akhmim, Upper Egypt: an assessment using water quality index and GIS techniques
}

\author{
Mohammed Hagage $^{1}$ - Ahmed A. Madani ${ }^{2}$ Salwa F. Elbeih ${ }^{1}$
}

Received: 16 July 2021 / Accepted: 21 December 2021 / Published online: 19 January 2022

(c) The Author(s) 2022

\begin{abstract}
The Quaternary aquifer has a special significance in Akhmim district, Upper Egypt, especially during the dry seasons, when surface water resources are insufficient and limited. In Akhmim district, the population mainly depends on groundwater for drinking, especially in spontaneous residential areas and inside agricultural lands. Therefore, assessing the groundwater quality is necessary to reduce diseases resulting from using polluted water in drinking. The Weighted Arithmetic Water Quality Index (WAWQI) was used for evaluating the groundwater quality, and it was classified according to the Egyptian and WHO standards and based on fifteen measured physicochemical parameters (TDS, $\mathrm{Na}, \mathrm{Cl}, \mathrm{Ca}, \mathrm{pH}, \mathrm{Mg}, \mathrm{NO}_{3}, \mathrm{SO}_{4}, \mathrm{TH}$, $\mathrm{Cr}, \mathrm{Cu}, \mathrm{Fe}, \mathrm{Pb}, \mathrm{Mn}$, and $\mathrm{Zn}$ ). To investigate the spatial distribution of WAWQI in Akhmim district, the spatial analyst tools (IDW method) were used. The WAWQI results showed a great diversity in groundwater viability for drinking due to the exposure of groundwater to many sources of degradation, identified through field verification and previous work about the study area. The groundwater of the Quaternary aquifer was divided into excellent, good, poor, very poor, and unsuitable. In addition, about 50\% of Akhmim district wells are inappropriate for drinking with classes ranging from unsuitable to poor. To use groundwater for drinking, the sources of degradation to which the groundwater is exposed must first be reduced, and the water should be treated before drinking.
\end{abstract}

Keywords Akhmim · Egypt · Groundwater quality · GIS · Weighted Arithmetic Water Quality Index (WAWQI)

\section{Introduction}

In recent years, the world has faced scarcity of freshwater resources due to the population increase, and urban sprawl, which exposed water resources to deterioration in both quantity and quality (Massoud 2012). Consequently, water quality control in many countries has become among the

Responsible Editor: Fethi Lachaal

This article is part of the Topical Collection on Water Quality, Global Changes and Groundwater Responses

Mohammed Hagage

mohammedhagage123@gmail.com

1 Engineering Applications and Water Division, National Authority for Remote Sensing and Space Sciences (NARSS), Cairo, Egypt

2 Geology Department, Faculty of Science, Cairo University, Cairo, Egypt highest priorities (Simeonov et al. 2002), especially, in arid and semiarid regions (Sayed et al. 2020). Continuity in evaluation and control of water quality helps in the continuous development of the strategies applied for pollution control (Yao et al. 2010).

There are many concerns about the lack of freshwater resources in Egypt, especially with the rapid population growth and the current threats to the main water resource (Nile River) from some upstream countries. Freshwater resources in Egypt are limited to about 55.5 billion $\mathrm{m}^{3} /$ year from the Nile River and about 6.20 billion $\mathrm{m}^{3} /$ year from the groundwater systems (Allam 1998). This amount of water does not meet Egypt's water needs, which prompted the country, through Egypt Vision 2030, to move forward in the search for nonconventional water resources such as seawater desalination and reuse of agricultural and sanitary drainage water through advanced treatment. Groundwater has become the main source of water for most agricultural reclamation projects in Egypt, especially 
in desert areas, which raises concerns about the sustainability of groundwater resources (El Arabi 2012).

Akhmim district in Upper Egypt is facing high rates of population increase and unplanned expansion of urban and industrial activities. This is accompanied by the everincreasing water crisis and snowballing production of sewage and other polluted water. Moreover, the desert fringes of the study area are being reclaimed for nonedible woodland using treated wastewater. These hazards worsen the environmental conditions of the whole area and can lead to further deterioration in the groundwater resources (Youssef et al. 2011; Ahmed and Ali 2011).

Generally, the quality of drinking water is evaluated according to several measured parameters (chemical, physical, and microbiological). The water is acceptable for human consumption if parameter values do not exceed the limits set by the WHO and the local health authorities in each country (WHO 2011; EMH 2007).

The effect of overall water quality parameters on the total water quality is expressed through the water quality index (WQI) (Horton 1965). WQI is the most effective method for assessing water quality for drinking purposes (Chowdhury et al. 2012). WQI simplifies a large set of values for many water quality parameters into a single value and simple ratings (e.g., excellent, good, bad, improper, etc.) that can be understood very easily by residents and decision-makers (Nasirian 2007; Chauhan and Singh 2010; Bharti and Katyal 2011).

The first water quality index was developed in 1965 by Horton using the arithmetic weighted average technique (Horton 1965). In 1970, some improvements were made to the Horton index (Brown et al. 1970). After that, many water quality indicators were formulated by many researchers and organizations such as Canadian Water Quality Index (CCMEWQI), National Sanitation Foundation Water Quality Index (NSFWQI), and Florida Stream Water Quality Index (FWQI) (SAFE 1995).

The Weighted Arithmetic Water Quality Index method (WAWQI) developed by (Brown et al. 1972) was used to assess the suitability of groundwater for drinking, where water quality is classified based on the most common water quality parameters and according to its degree of purity (Smith 1989). WAWQI has been used by many scientists (Balogun et al. 2012; Negm and Armanuos 2016; Howladar et al. 2017; Tiwari et al. 2018; Vaiphei et al. 2020; Ahmed et al. 2020) because it has many advantages compared to other methods. One of which is that it has the ability to describe the suitability of both groundwater and surface water for drinking purposes (Tyagi et al. 2013), being free from overestimation or underestimation (Sharma et al. 2016), and it is based on a mathematical equation that includes several water quality parameters without depending on certain parameters (Chandra et al. 2017; El Zeiny and Elbeih 2019).

Geographic information system (GIS) has essential roles in all aspects related to the management and development of water resources such as assessing groundwater quality, mapping, and assessing groundwater vulnerability and suitability analyses. GIS programs contain spatial analysis tools that have the ability to deal with huge data (Madhloom and Alansari 2018).

Many researchers interested in evaluating groundwater for drinking purposes have used the WQI and inverse distance weighting (IDW) interpolation method in GIS programs. Chabuk et al. (2020) assessed the water quality of the Tigris River, Iraq, using the WQI and the IDW method where the results showed deterioration in the water quality downstream the river. El Zeiny and Elbeih (2019) used the WQI and IDW method to evaluate the groundwater quality in Dakhla Oasis, Egypt, for drinking purposes according to the Egyptian and WHO standards, where the results showed that about 38\% of the wells fall into the category of poor water. Ewaid and Abed (2017) used the WQI to assess the water quality of the Gharraf River in southern Iraq through five stations along the river. The WQI rated the river water as good for drinking in station 1 , weak in stations 2,3 , and 4 , and very weak in station 5. Magesh et al. (2013) assessed groundwater quality in Tamil Nadu region, India, using the WQI and GIS where the results showed that most of the groundwater samples are suitable for drinking.

This study aims to assess the suitability of groundwater quality in Akhmim district for drinking purposes by applying the WQI. Spatial analysis tools in ArcGIS program were used to produce spatial distribution maps of groundwater quality, and the reasons for the unsuitability of groundwater for drinking were determined, based on field verification and published studies.

\section{Methodology}

\section{Description of the study area}

Akhmim district is located east of the River Nile in Sohag Governorate between longitudes $31^{\circ} 35^{\circ}$ and $31^{\circ} 55^{\circ} \mathrm{E}$ and latitudes $26^{\circ} 30^{\circ}$ and $26^{\circ} 38^{\circ} \mathrm{N}$ (Fig. 1). The major geomorphological features in Akhmim area include the cultivated Nile flood plain, the Eocene limestone plateau, and the lowland desert areas (Youssef and Abdel Moneim 2006).

In the lowland desert area, south of Akhmim (El-Kola area), treated wastewater is used in the cultivation of woody trees, but this area is insufficient to accommodate the wastewater quantities resulting from the treatment plant. As a result, the wastewater accumulates on the ground surface 
Fig. 1 Location and geological map of Akhmim district (EGSMA 1983)

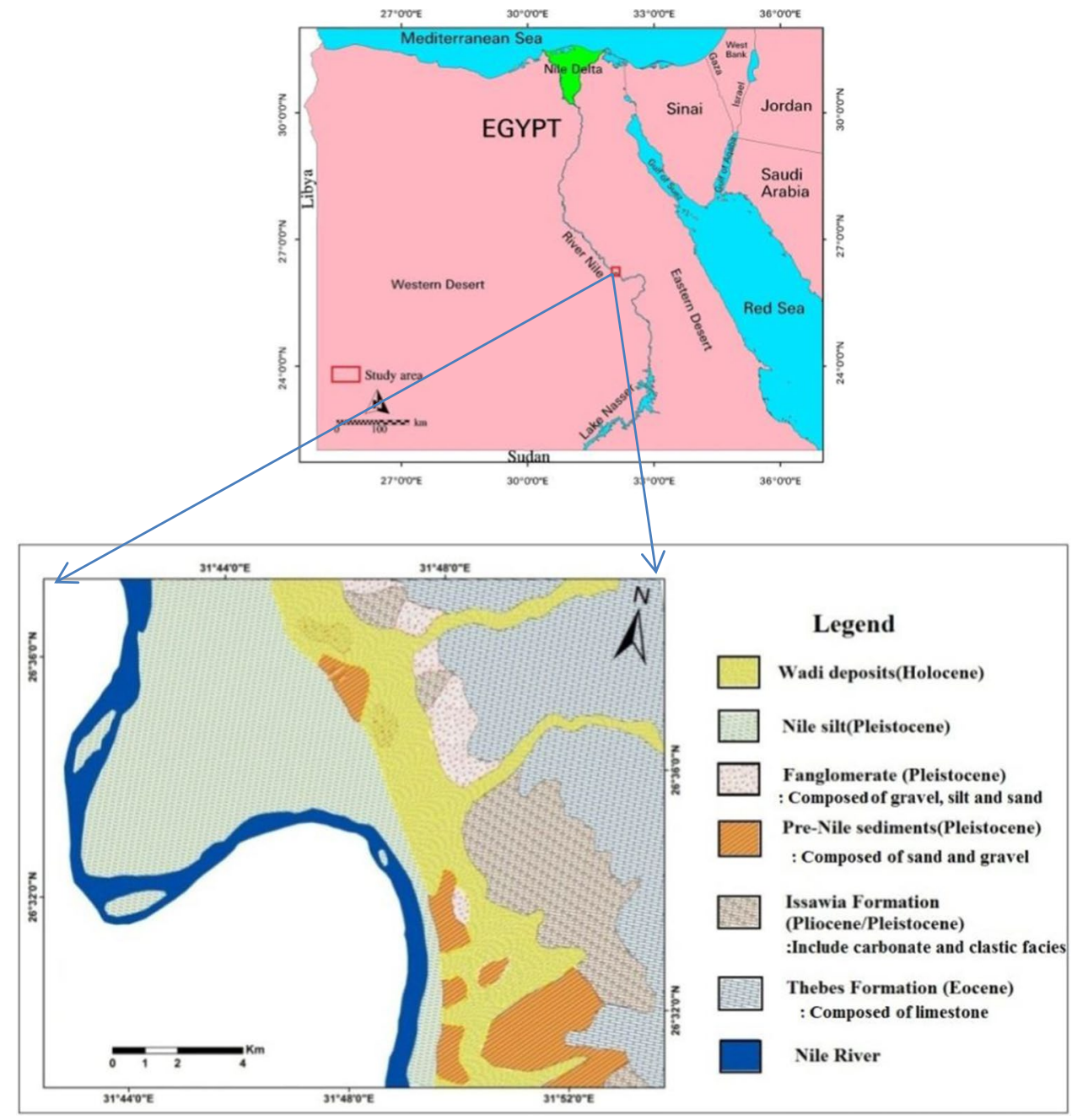

forming large pools (Youssef et al. 2011). In the last few years, many industrial areas were built in Sohag Governorate, where Al-Kawser city is one of these areas and is located north of Akhmim district (Ahmed 2009).

The sedimentary sequence in Akhmim area consists of rock units that extend from Eocene to Recent. The major aquifer in Akhmim area is the Quaternary aquifer system where the Pleistocene deposits are the major water-bearing sediments (Abdel Moneim 1999). On ancient cultivated lands, the Quaternary aquifer is a semi-confined aquifer where the upper member consists of a clay-silt layer, while in the desert fringes, it is an unconfined aquifer, and the clay-silt layer is replaced by desert sands. The groundwater flows towards the River Nile where the groundwater level in Akhmim area ranges from $63 \mathrm{~m}$ (masl) at the valley fringes to $53 \mathrm{~m}$ (masl) near the River Nile. Return flow from irrigation (excess irrigation water) is the essential source of groundwater recharge, and extraction by pumping wells is the major source of discharge (Ahmed 2007).

The groundwater has a special importance in the study area, as it is used mainly for drinking, especially in random residential areas scattered along the roads and inside agricultural lands. However, it is presently threatened by pollution from urbanization, agricultural activities, and wastewater used in agriculture (Ahmed and Ali 2011). The main pollution source resulting from domestic activities includes leakage from sewage system, septic tanks, and probable release of wastewater from wastewater disposal sites (Ali 2005; Youssef and Abdel Moneim 2006; Elbeih et al. 2021; Hagage 2021). The development projects in the desert zone of Sohag Governorate represent a new source of groundwater contamination for the Quaternary aquifer (Ahmed 2009).

Figure 2 shows the flow chart for the methodology used to determine groundwater suitability for drinking purposes in the study area.

\section{Sampling of groundwater and analysis}

Thirty-two groundwater samples representing the Quaternary aquifer system were collected in April 2019. The well coordinates were recorded using Garmin Handheld GPS (Fig. 3). 
Fig. 2 Flowchart of materials and method steps

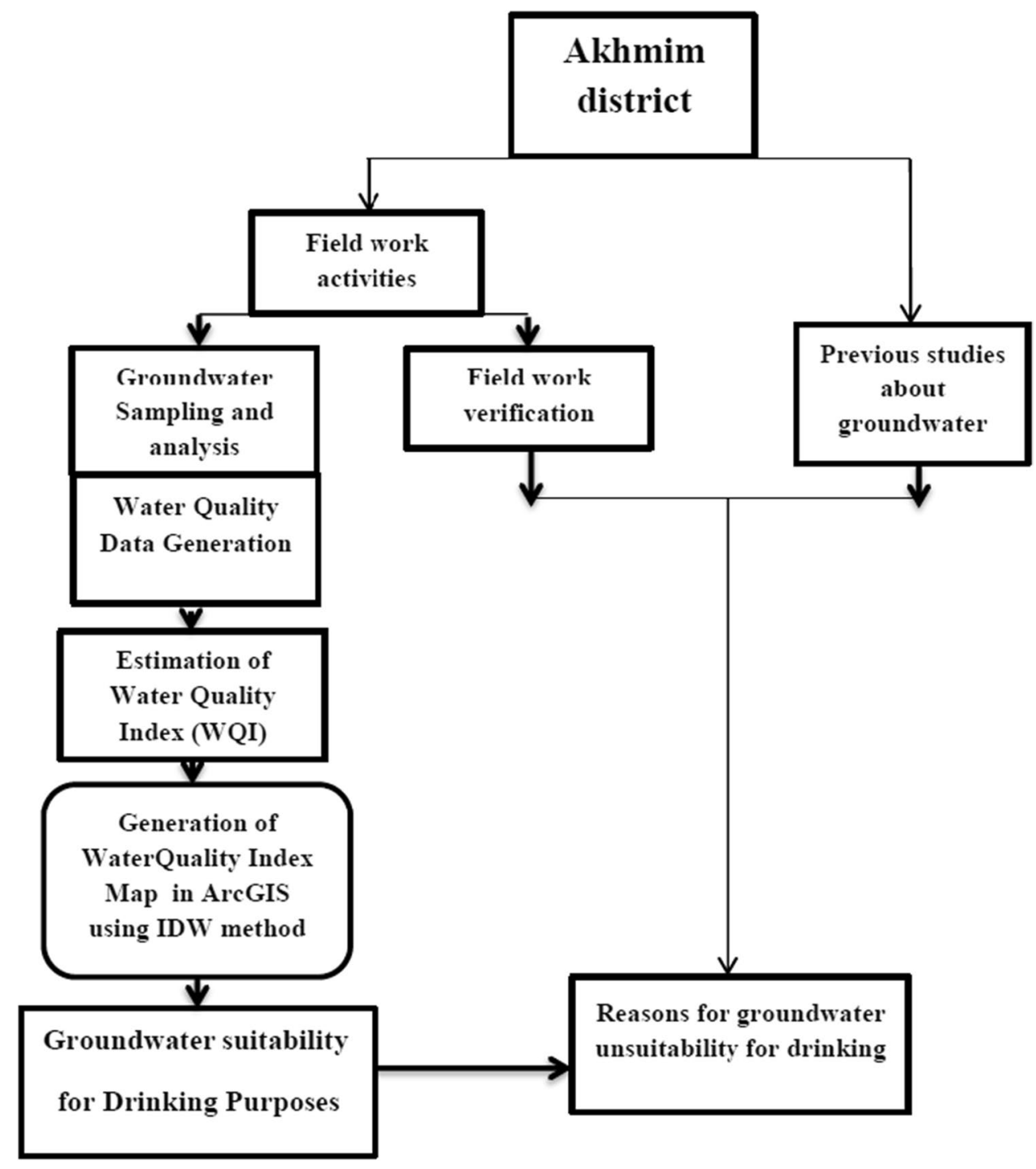

The wells were pumped for 10 min prior to sample collection to avoid stagnant water from the boreholes and rinsing the bottles several times with the groundwater prior filling with water to minimize any contamination. Two bottles were collected from each well, 11 bottle and another bottle of $100 \mathrm{ml}$ acidified with nitric acid (1\%) for heavy metals analysis and preserved separately, and all water samples were closed carefully and labeled after collection and preserved in an icebox until analysis. In the central laboratory of the National Water Research Center, analysis was carried out, where cations, anions, nutrients, and soluble heavy metals were determined.

\section{Water quality index calculation}

In this study, the Weighted Arithmetic Water Quality Index (WAWQI) method was used. The water quality was classified according to the Egyptian Ministry of Health and
Population (EMH 2007) and World Health Organization (WHO) standards (WHO 2011) based on fifteen measured parameters (TDS, Cl, Ca, $\mathrm{Na}, \mathrm{Mg}, \mathrm{pH}, \mathrm{NO}_{3}, \mathrm{SO}_{4}, \mathrm{TH}, \mathrm{Cr}$, $\mathrm{Cu}, \mathrm{Fe}, \mathrm{Pb}, \mathrm{Mn}$, and $\mathrm{Zn}$ ).

\section{Weighted arithmetic water quality index}

The WAWQI was developed by Brown et al. (1972), and it is determined using the next equations:

$W A W Q I=\frac{\sum Q_{i} W_{i}}{\sum W_{i}}$

where,

$\left(\mathrm{W}_{\mathrm{i}}\right)$ is the relative weight of $\mathrm{i}^{\text {th }}$ parameter.

$\left(\mathrm{Q}_{\mathrm{i}}\right) \quad$ is a quality rating scale for the $\mathrm{i}^{\text {th }}$ parameter. 
Fig. 3 Groundwater sampling locations in Akhmim district

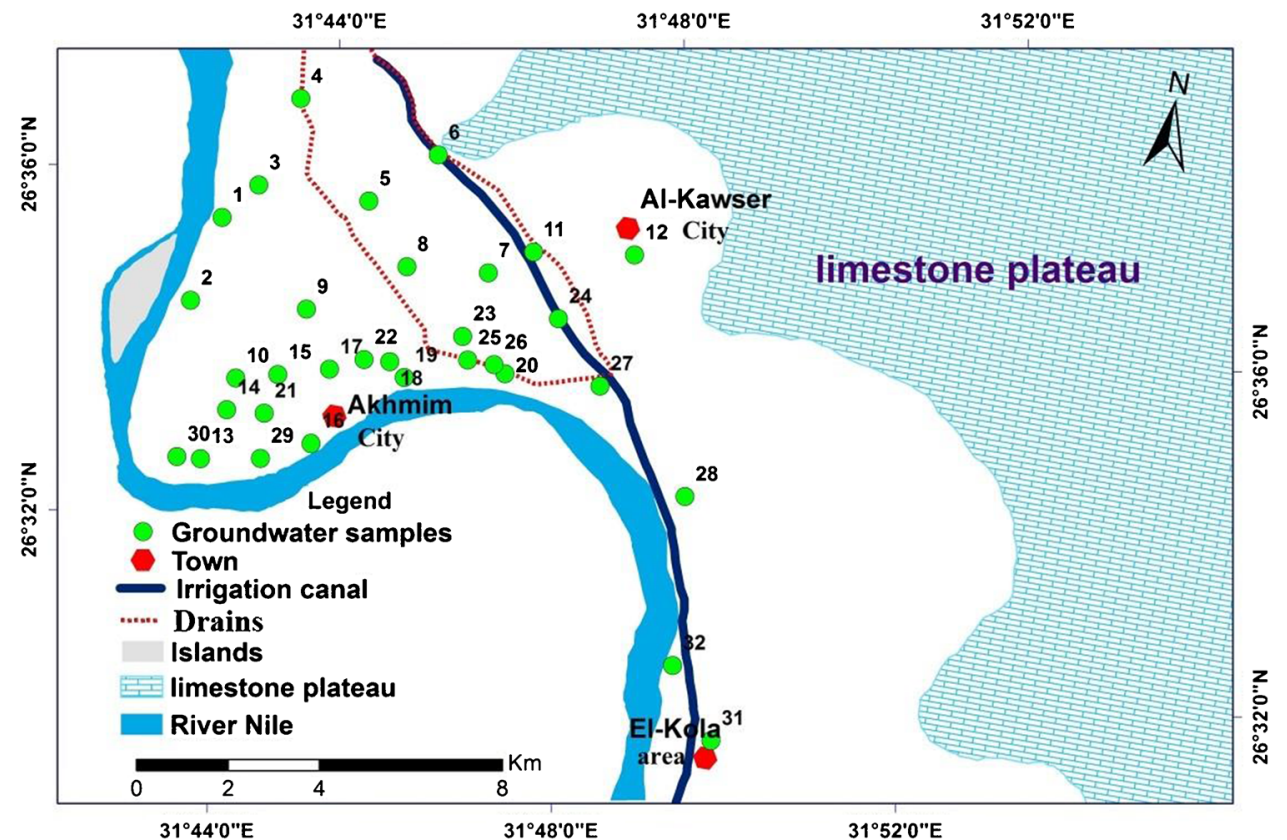

Table 1 Water quality classification according to WAWQI (Brown et al. 1972)

\begin{tabular}{ll}
\hline WAWQI rating & Water quality \\
\hline $0-25$ & Excellent \\
$26-50$ & Good \\
$51-75$ & Poor \\
$76-100$ & Very poor \\
Above 100 & Unsuitable \\
& for drinking \\
& purpose \\
\hline
\end{tabular}

The water quality classification based on the above calculated WAWQI using Eq. 1 is given in Table 1.

The following steps were used to determine the WAWQI.

\section{1- Calculation of quality rating scale $\left(\mathrm{Q}_{\mathrm{i}}\right)$}

$\mathrm{Q}_{\mathrm{i}}$ is a number that reflects the ratio of the concentrations of different water quality parameters in relation to its standard value and is calculated by Eq. 2:

$Q_{i}=\frac{V_{i-} V_{0}}{S_{i-} V_{0}} * 100$

where,

$\left(\mathrm{V}_{\mathrm{i}}\right)$ estimated concentration of $\mathrm{i}^{\text {th }}$ parameter in the analyzed water sample.

$\left(\mathrm{V}_{0}\right)$ the ideal value of this parameter in pure water, $V_{0}=0$ (except for dissolve oxygen $=14.6$ and $\mathrm{pH}=7.0$ ).
$\left(\mathrm{S}_{\mathrm{i}}\right) \quad$ the recommended standard value of $\mathrm{i}^{\text {th }}$ parameter (WHO 2011; EMH 2007).

The World Health Organization (WHO 2011) and the Egyptian Ministry of Health (EMH 2007) have standard values of maximum allowable limits for the parameters measured in drinking water as shown in Table 2.

\section{2- Calculation of relative weight $\left(\mathrm{W}_{\mathrm{i}}\right)$}

To calculate the relative weight, different weights were assigned to the measured parameters according to their impact on water quality used for drinking purposes, potential health effects, and according to researchers opinions (Balogun et al. 2012; Ambiga and Durai 2013; Anbazhagan and Jothibasu 2014; Negm and Armanuos 2016; Howladar et al. 2017; Tiwari et al. 2018; Vaiphei et al. 2020; Ahmed et al. 2020). Researchers have assigned the weights of parameters in the range from 1 to 5 . The highest weights ( 5 and 4 ) have been assigned to parameters such as TDS, $\mathrm{NO}_{3}, \mathrm{SO}_{4}, \mathrm{Cr}, \mathrm{Fe}$, and $\mathrm{Pb}$ due to their major importance in water quality assessment for drinking. On the other hand, weights of 3 and 2 were assigned to other parameters such as $\mathrm{pH}, \mathrm{Ca}, \mathrm{Mg}, \mathrm{Cl}$, and $\mathrm{Na}$ depending on their importance in the overall water quality. The lowest weight (1) has been assigned to parameters $\left(\mathrm{HCO}_{3}\right)$ which is considered of less impact on the water quality.

The relative weight $\left(\mathrm{W}_{\mathrm{i}}\right)$ is calculated using the next formula (Singh 1992):

$W_{i=\frac{w_{i}}{\sum_{i=1}^{n} w_{i}}}$

where, 
Table 2 Maximum allowable limits for the parameters measured in drinking water

\begin{tabular}{lll}
\hline Parameters & $\begin{array}{l}\text { Egyptian maximum allowable limit } \\
\text { (EMH 2007) }\end{array}$ & $\begin{array}{l}\text { WHO maximum } \\
\text { allowable limit (WHO } \\
2011)\end{array}$ \\
\hline $\mathrm{pH}$ & $6.5-8.5$ & $6.5-8.5$ \\
Total dissolved solids (TDS) mg/l & 1000 & 1000 \\
Calcium $(\mathrm{Ca}) \mathrm{mg} / \mathrm{l}$ & 200 & 200 \\
Magnesium $(\mathrm{Mg}) \mathrm{mg} / \mathrm{l}$ & 150 & 130 \\
Sodium $(\mathrm{Na}) \mathrm{mg} / \mathrm{l}$ & 200 & 200 \\
Chloride $(\mathrm{Cl}) \mathrm{mg} / \mathrm{l}$ & 250 & 200 \\
Nitrate $(\mathrm{No}) \mathrm{mg} / \mathrm{l}$ & 45 & 50 \\
Sulfate $(\mathrm{SO})_{4} \mathrm{mg} / \mathrm{l}$ & 250 & 200 \\
Total hardness $(\mathrm{TH})$ & 500 & 500 \\
Chromium $(\mathrm{Cr}) \mathrm{mg} / \mathrm{l}$ & 0.05 & 0.05 \\
Copper $(\mathrm{Cu}) \mathrm{mg} / \mathrm{l}$ & 1 & 1.5 \\
Iron $(\mathrm{Fe}) \mathrm{mg} / \mathrm{l}$ & 0.3 & 0.3 \\
Lead $(\mathrm{Pb}) \mathrm{mg} / \mathrm{l}$ & 0.05 & 0.01 \\
Manganese $(\mathrm{Mn}) \mathrm{mg} / \mathrm{l}$ & 0.1 & 0.1 \\
Zinc $(\mathrm{Zn}) \mathrm{mg} / \mathrm{l}$ & 5 & 5 \\
\hline
\end{tabular}

Table 3 Weight and relative weight of parameters

\begin{tabular}{lll}
\hline Parameters & Weight $\left(\mathrm{w}_{\mathrm{i}}\right)$ & $\begin{array}{l}\text { Relative weight } \\
\left(\mathrm{W}_{\mathrm{i}}\right)=\mathrm{w}_{\mathrm{i}} / \sum_{i=1}^{n} \boldsymbol{w}_{\boldsymbol{i}}\end{array}$ \\
\hline $\mathrm{TDS}$ & 5 & 0.098 \\
$\mathrm{pH}$ & 3 & 0.059 \\
$\mathrm{Ca}$ & 2 & 0.039 \\
$\mathrm{Mg}$ & 2 & 0.039 \\
$\mathrm{Na}$ & 3 & 0.059 \\
$\mathrm{Cl}$ & 3 & 0.059 \\
$\mathrm{NO}_{3}$ & 5 & 0.098 \\
$\mathrm{SO}_{4}$ & 4 & 0.078 \\
$\mathrm{TH}$ & 2 & 0.039 \\
$\mathrm{Cr}$ & 4 & 0.078 \\
$\mathrm{Cu}$ & 3 & 0.059 \\
$\mathrm{Fe}$ & 4 & 0.078 \\
$\mathrm{~Pb}$ & 4 & 0.078 \\
$\mathrm{Mn}$ & 4 & 0.078 \\
$\mathrm{Zn}$ & 3 & 0.059 \\
$\mathrm{Sum}$ & 51 & 1 \\
\hline
\end{tabular}

wi is the weight of the ith parameter.

The weights assigned to the different parameters, as well as the relative weights calculated, are presented in Table 3.

\section{GIS analyses}

The inverse distance weighting (IDW) interpolation method in ArcGIS V.10.2 software was used to investigate the spatial distribution of WAWQI in Akhmim district. This method is the most widely used by earth and water scientists compared with other spatial analysis tools because of its high accuracy (Madhloom and Alansari 2018). The assumption that IDW interpolation method relied upon is that sites close to each other are more similar than those far away from each other (Lu and Wong 2008).

\section{Field verification}

After calculating the water quality index and identifying the areas that suffer from unsuitability of groundwater for drinking, the results were confirmed through:

(1) Field verification to identify the reasons for the unsuitability of groundwater for drinking in these areas.

(2) Published studies on groundwater quality in Sohag Governorate (Youssef and Abdel Moneim 2006; Youssef et al. 2011; Ahmed and Ali 2011; Elbeih et al. 2021; Hagage 2021).

\section{Results and discussion}

\section{Groundwater quality using WQI}

The WQI was calculated, in order to estimate the suitability of groundwater in Akhmim area for drinking. Statistical analysis of the physical and chemical properties of the groundwater samples that were applied in the calculation of the WQI is shown in Table 4.

WAWQI results showed a great diversity in groundwater viability for drinking where the groundwater in Akhmim district was divided into categories: unsuitable, very poor, poor, good, and excellent. The results of applying WAWQI for drinking purposes are shown in Table 5. The percentages of WAWQI according to the Egyptian standards and WHO standards are shown in Fig. 4. 
Table 4 Statistical analysis of the measured parameters of the groundwater samples

\begin{tabular}{lllll}
\hline Parameters & Units & Minimum & Maximum & Mean \\
\hline $\mathrm{TDS}$ & $\mathrm{mg} / \mathrm{l}$ & 228 & 3088 & 756 \\
$\mathrm{pH}$ & - & 7.2 & 7.8 & 7.52 \\
$\mathrm{TH}$ & $\mathrm{mg} / \mathrm{l}$ & 156 & 894 & 251 \\
$\mathrm{Na}$ & $\mathrm{mg} / \mathrm{l}$ & 17 & 750 & 130 \\
$\mathrm{Ca}$ & $\mathrm{mg} / \mathrm{l}$ & 52 & 176 & 81 \\
$\mathrm{Mg}$ & $\mathrm{mg} / \mathrm{l}$ & 10 & 35 & 26 \\
$\mathrm{No}_{3}$ & $\mathrm{mg} / 1$ & 0.2 & 125 & 16 \\
$\mathrm{CL}$ & $\mathrm{mg} / 1$ & 21 & 1087 & 124 \\
$\mathrm{SO}$ & $\mathrm{mg} / \mathrm{l}$ & 27 & 493 & 93 \\
$\mathrm{~Pb}$ & $\mathrm{mg} / 1$ & 0.004 & 0.05 & 0.025 \\
$\mathrm{Mn}$ & $\mathrm{mg} / \mathrm{l}$ & 0.004 & 1.3 & 0.168 \\
$\mathrm{Cr}$ & $\mathrm{mg} / \mathrm{l}$ & 0.002 & 0.02 & 0.011 \\
$\mathrm{Cu}$ & $\mathrm{mg} / 1$ & 0.011 & 0.23 & 0.03 \\
$\mathrm{Fe}$ & $\mathrm{mg} / 1$ & 0.006 & 0.14 & 0.030 \\
$\mathrm{Zn}$ & $\mathrm{mg} / 1$ & 0.01 & 1.81 & 0.177 \\
\hline
\end{tabular}

Spatial distribution maps of WQI according to the Egyptian and WHO standards were created for study area as shown in Figs. 5 and 6. According to WHO standards, the groundwater in Akhmim district is divided into four categories: good, poor, very poor, and unsuitable for drinking. The unsuitable groundwater in Akhmim district is about $4 \%$ of the total area (Akhmim city, El-Kola area), while $11.5 \%$ is located in very poor groundwater quality (as Al-Kawser city). The good groundwater area is about $35.5 \%$, while most parts of Akhmim district (49\%) have poor groundwater quality.

According to the Egyptian standards, the groundwater in Akhmim district is divided into categories: excellent, good, poor, very poor, and unsuitable for drinking. The unsuitable groundwater for drinking in Akhmim district is about $2 \%$ of the total area (Akhmim city, El-Kola area), while 5\% is located in very poor groundwater quality (as Al-Kawser city). The excellent groundwater area is about $0.5 \%$ and the poor groundwater quality is about $35.5 \%$ of the study area. In most parts of Akhmim district (57\%), groundwater is good.

The results obtained after applying both standards are very close to each other, as the very poor quality of water and unsuitable for drinking are concentrated in Akhmim city, AlKawser city, and El-Kola area. Both guidelines are applicable for such types of study.

\section{Reasons for groundwater unsuitability for drinking in the study area}

In Akhmim area, it is assumed that water in canals and drains is the main source for groundwater recharge and the main factor controlling its quality. Recently, other sources have emerged
Table 5 WQI values and groundwater viability for drinking in Akhmim district

\begin{tabular}{|c|c|c|c|c|}
\hline \multirow[t]{2}{*}{ Well no } & \multicolumn{2}{|c|}{ Egypt standards (2007) } & \multicolumn{2}{|c|}{ WHO standards (2011) } \\
\hline & WQI & Water type & WQI & Water type \\
\hline 1 & 36.6 & Good & 51.7 & Poor \\
\hline 2 & 28.2 & Good & 31 & Good \\
\hline 3 & 19.1 & Excellent & 22 & Excellent \\
\hline 4 & 24.1 & Excellent & 37.7 & Good \\
\hline 5 & 35.9 & Good & 40 & Good \\
\hline 6 & 25.5 & Good & 27.8 & Good \\
\hline 7 & 30 & Good & 34.4 & Good \\
\hline 8 & 50.9 & Poor & 61.4 & Poor \\
\hline 9 & 60.1 & Poor & 63.3 & Poor \\
\hline 10 & 25.9 & Good & 31.3 & Good \\
\hline 11 & 35.5 & Good & 41.5 & Good \\
\hline 12 & 86.9 & Very poor & 98 & Very poor \\
\hline 13 & 30.8 & Good & 58.5 & Poor \\
\hline 14 & 32.3 & Good & 42.8 & Good \\
\hline 15 & 38 & Good & 48 & Poor \\
\hline 16 & 61.4 & Poor & 84.5 & Very poor \\
\hline 17 & 34.5 & Good & 53 & Poor \\
\hline 18 & 34.1 & Good & 44.2 & Good \\
\hline 19 & 123 & Unsuitable & 136 & Unsuitable \\
\hline 20 & 58.5 & Poor & 75.5 & Very poor \\
\hline 21 & 32.5 & Good & 50.5 & Poor \\
\hline 22 & 35.5 & Good & 65.2 & Poor \\
\hline 23 & 56.4 & Poor & 63.7 & Poor \\
\hline 24 & 50.1 & Poor & 82.4 & Very poor \\
\hline 25 & 35.1 & Good & 67.1 & Poor \\
\hline 26 & 62.9 & Poor & 79.1 & Very poor \\
\hline 27 & 39.8 & Good & 59.5 & Poor \\
\hline 28 & 36.5 & Good & 51 & Poor \\
\hline 29 & 57.4 & Poor & 62.5 & Poor \\
\hline 30 & 57.5 & Poor & 69.5 & Poor \\
\hline 31 & 119 & Unsuitable & 138 & Unsuitable \\
\hline 32 & 17.5 & Excellent & 27.3 & Good \\
\hline
\end{tabular}

that contribute to the groundwater recharge and accordingly to the quality of groundwater and led to further degradation. These other sources include urbanization, agricultural activities, and using wastewater in agriculture indiscriminately and without proper control (Ali 2005; Ahmed 2009).

The spatial distribution maps of WQI in Akhmim district show that the entire study area suffers from groundwater quality deterioration. The areas that suffer severely from such deterioration and the unsuitability of groundwater for drinking are Akhmim city, Al-Kawser city, and El-Kola area. The reasons for groundwater deterioration and its unsuitability for drinking were determined through field verification and published studies (Omer et al. 2005; Youssef and Abdel Moneim 2006; Ahmed 2009; Youssef et al. 2011; 
Fig. 4 The percentages of WQI categories according to Egyptian and WHO standards
Fig. 5 Spatial distribution of WQI according to the WHO standards
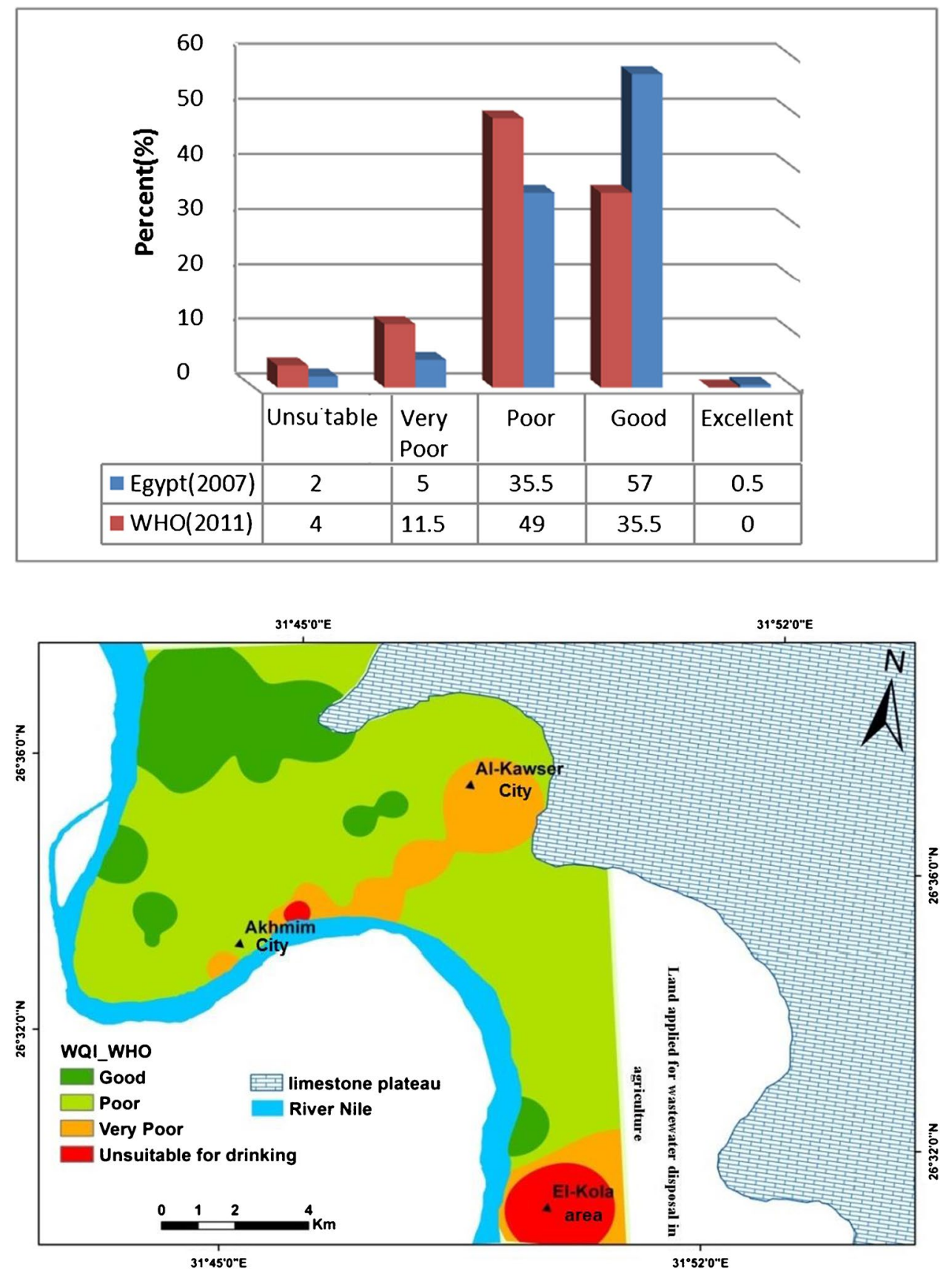

Elbeih et al. 2021; Hagage 2021), which can be clarified in the following points:

1- Using septic tanks (sewage rooms) and injection wells to get rid of sewage

In Akhmim district, built-up areas expanded from $9189.9 \mathrm{~km}^{2}$ in 1990 to $13,696.2 \mathrm{~km}^{2}$ in 2019 (Elbeih et al. 2021). Population growth and urbanization without proper urban planning in the study area generated random sewage systems as the only way to get rid of sewage, especially in rural areas and scattered settlements (Fig. 7).
Sewage rooms are the popular disposal facility used in the study area. These rooms are built in a way that sewage water percolates from the walls and bottoms leading to further groundwater deterioration (Ahmed and Ali 2011). The second form of random sewage systems is the use of injection wells in some areas for sewage disposal. The amount of sewage pumped into the groundwater aquifer depends on the population density and the amount of water consumed for domestic purposes (EEAA 1997).

2- Discharging liquid industrial wastes into the ground without proper treatment 
Fig. 6 Spatial distribution of WQI according to the Egyptian standards
Fig. 7 Expansion in built-up areas based on two multispectral Landsat images (L.S 5 TM and L.S 8 OLI), dated 2nd of February 1990 and 23rd of April 2019 (Elbeih et al. 2021)
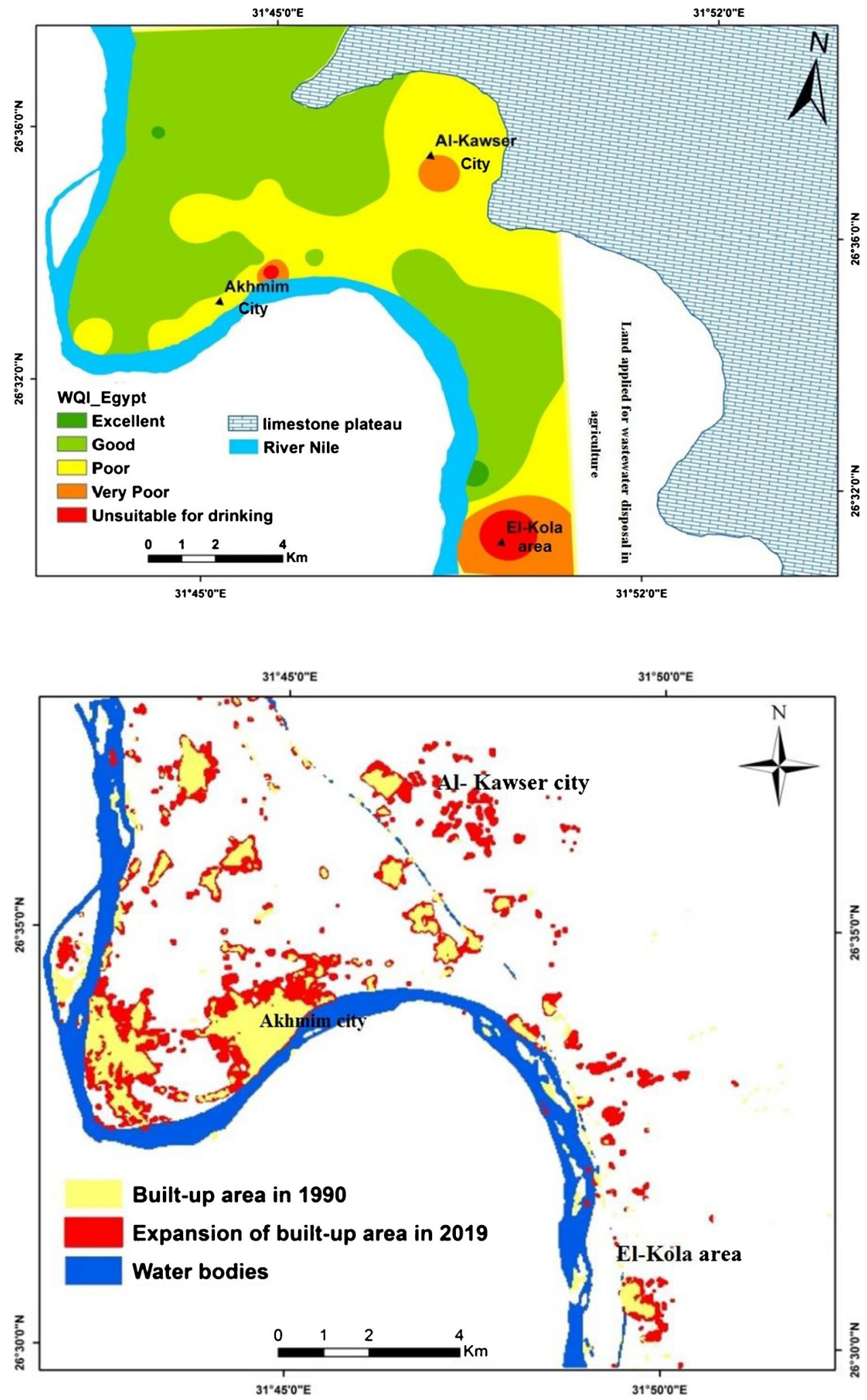

Al-Kawser city is the main source of industrial pollution of groundwater in Akhmim district, where the factories there lack proper treatment and sewage systems. There are major factories in the area for sugar, soft drinks, garment industries, and oil dehydration industries. One of the major problems facing these industrial communities is the potential health and environmental hazard posed by industrial wastewater. Untreated wastewater discharged by industrial 
Fig. 8 Land applied for wastewater disposal in 4 April 2019 (sources of images are Google Earth)

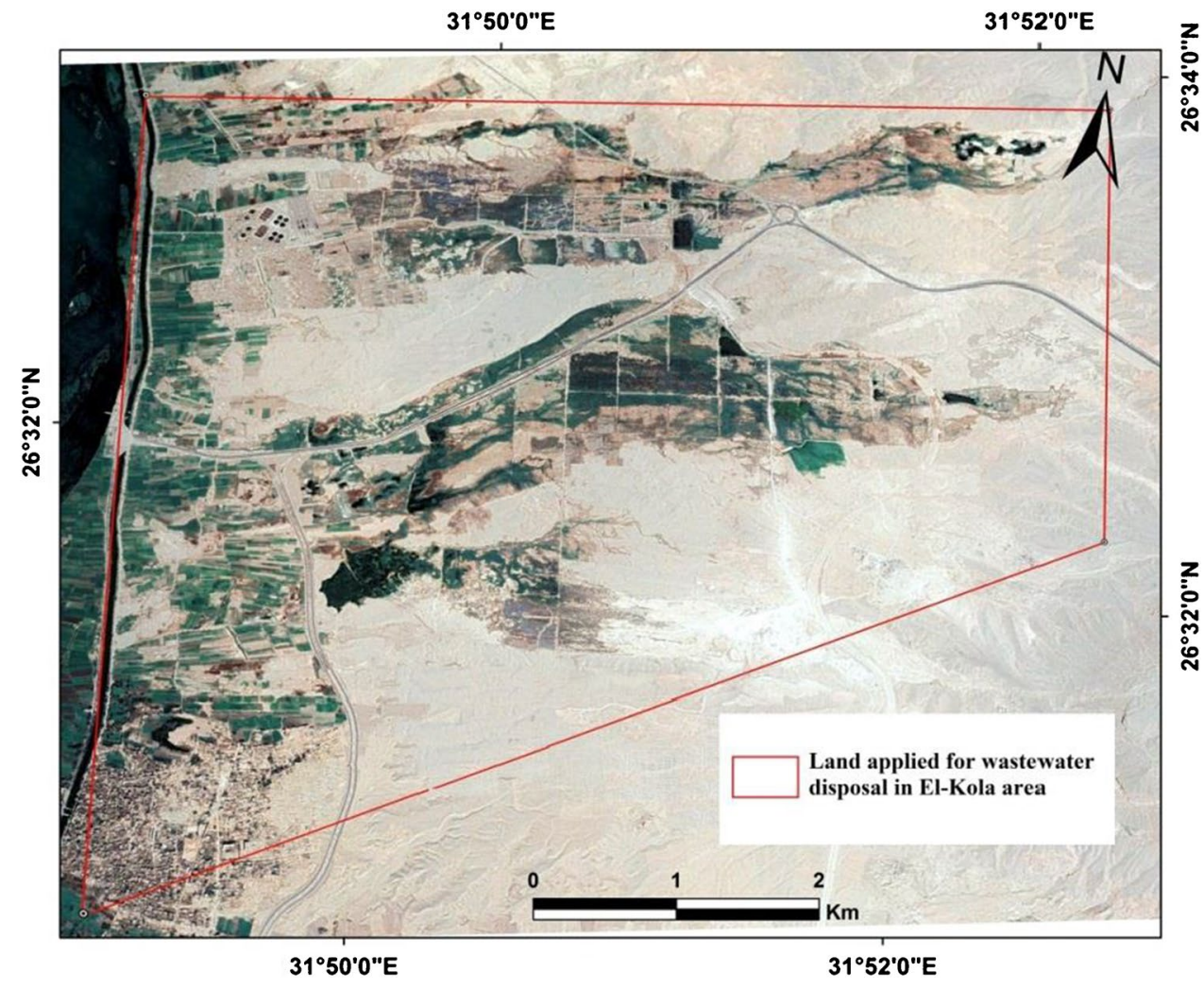

activities is often contaminated by a variety of toxic or harmful substances (El-Gohary et al. 2002). Most factories discharge their liquid wastes into subsurface tanks. Pollutants seep into the groundwater, especially west of Al-Kawthar area, where the water level is relatively shallow, and the rate of infiltration of soil sand and silt is considerably high (Youssef and Abdel Moneim 2006).

\section{3- Using treated wastewater in irrigation}

Secondary treated wastewater is used for irrigation of woody farmlands in the desert area east of El-Kola area in a random manner. Irrigation in this area takes place without applying the conditions and rules established by the Food and Agriculture Organization (FAO 2003) regarding using treated wastewater in agriculture (Fig. 8). More than 28,000 $\mathrm{m}^{3} /$ day of treated wastewater from the El-Kola treatment plant is used in irrigating the woody farmlands (Egyptian Ministry of Environment 2019).

The random use of wastewater in agriculture led to its accumulation on the earth's surface, creating large ponds at the site as shown in Fig. 9. The geology of the region may have a role in the formation of these ponds. Youssef et al. (2011) mentioned that El-Kola site has a unique geological advantage, the presence of a dense Pliocene clay layer very close to the surface, which greatly enhances the formation
Fig. 9 Wastewater pools in the land applied for wastewater disposal

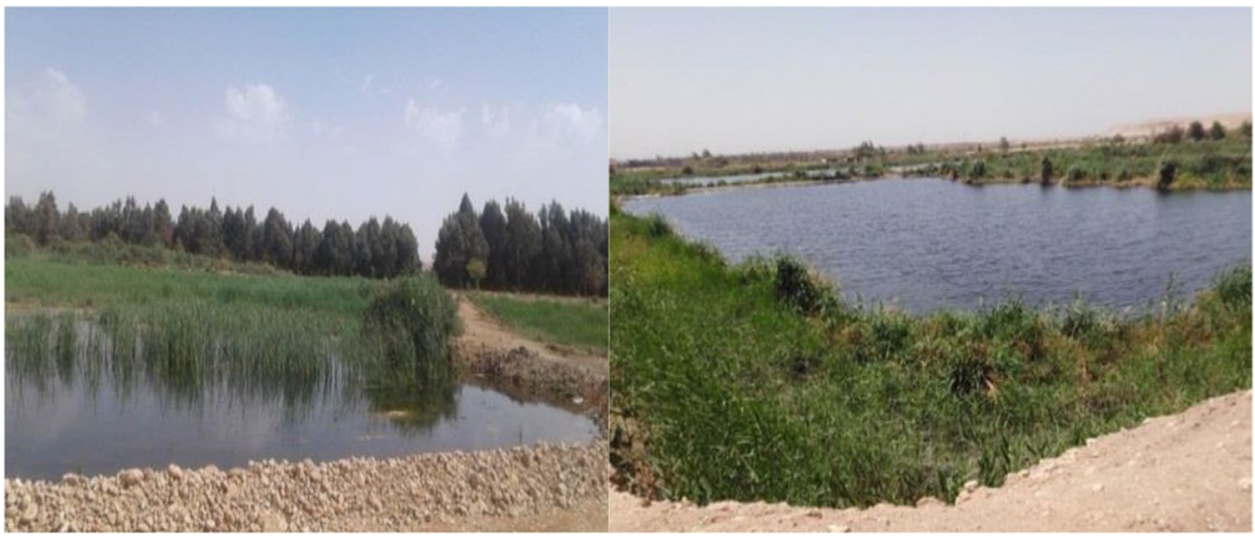


Fig. 10 A Aster Global Digital Elevation Model (AS TGDEM) showing the topography of the study area (Hagage 2021). B Detailed cross section in El-Kola disposal site showing the subsurface succession in the area and the expected flow direction of water (Youssef and Abdel Moneim 2006)

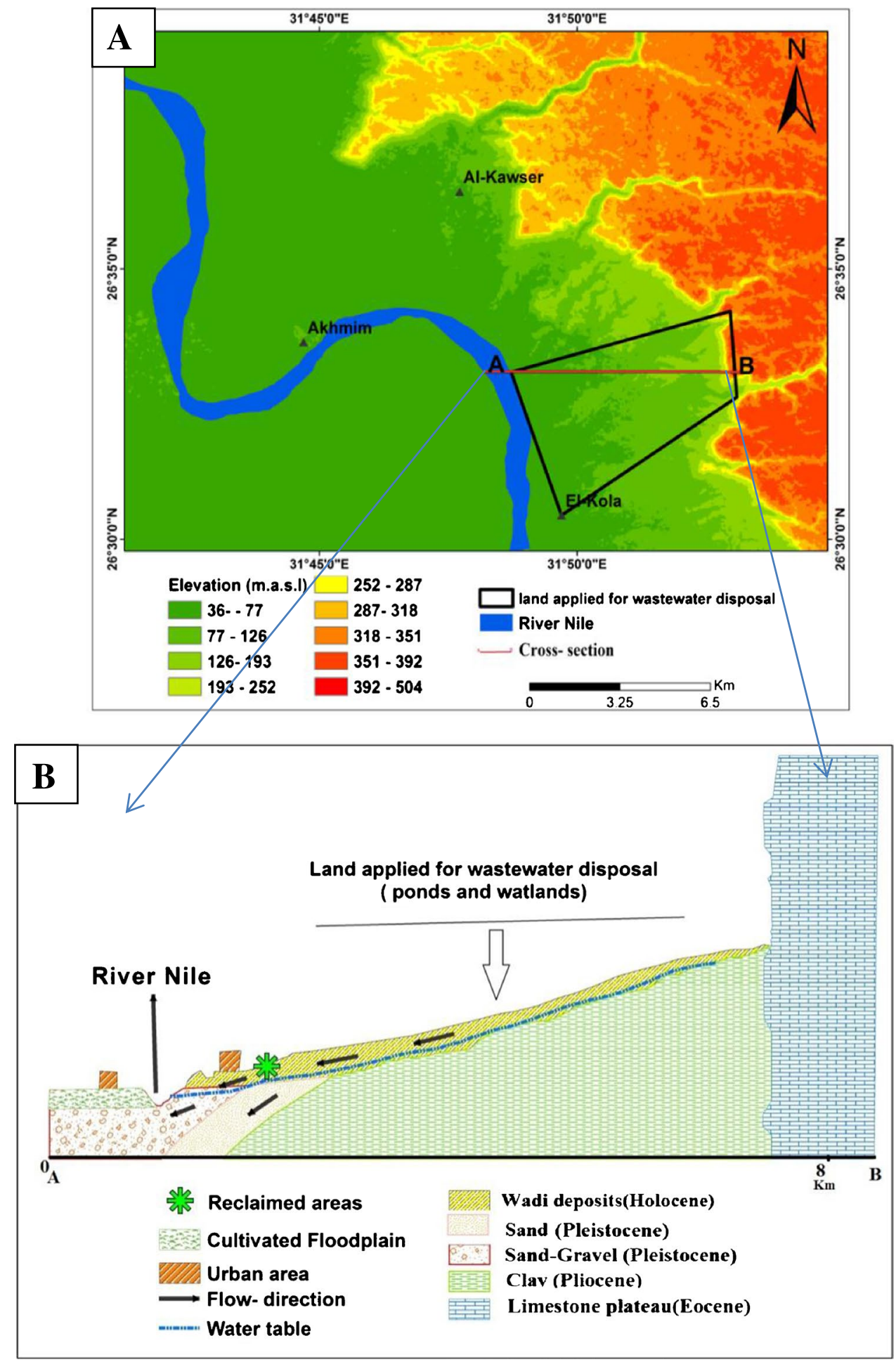

of these ponds (Fig. 10). This Pliocene clay represents a barrier against water to penetrate downwards to the subsurface layers, and hence several ponds are formed.

There are different types of seepage of treated wastewater at this area including seepage due to irrigation method, seepage from the pipelines, and seepage from the ponds (Youssef and Abdel Moneim, 2006). Wastewater accumulated in the land applied for wastewater disposal can be infiltrate down and reach the groundwater where the sediments in this area are classified as coarse textured sediments where the sand fraction is predominant, the hydraulic conductivity ranges from 1.5 to $26 \mathrm{~cm} / \mathrm{h}$, which reflects good permeability of these deposits (Omer et al., 2005). 
As a result of the ground surface slope to the west and the presence of a layer of dense Pliocene clay very close to the surface in the land applied for wastewater disposal (Fig. 10), water accumulating moves towards the groundwater aquifer (Elbeih et al. 2021), which pollutes the groundwater in the area (Ali 2005; Ahmed 2009).

\section{Conclusion and recommendations}

Akhmim district is located east of Sohag Governorate, Upper Egypt, and is facing a high rate of population increase and unplanned expansion of urban and industrial activities that could lead to further deterioration in the groundwater quality. Akhmim district depends mainly on groundwater for drinking, especially in the summer where the surface water is insufficient and limited. Therefore, assessing groundwater quality is necessary to reduce diseases resulting from the use of polluted water in drinking.

The suitability of groundwater for drinking was assessed using the WAWQI method developed by Brown et al. (1972), according to the Egyptian and WHO standards, and based on thirty-two groundwater samples collected from Akhmim district. The spatial distribution of groundwater suitability for drinking was shown using the spatial analysis tools in ArcGIS software.

WAWQI results showed a great diversity in groundwater viability for drinking as the groundwater was divided into excellent, good, poor, very poor, and unsuitable for drinking. About $50 \%$ of the wells of Akhmim district are inappropriate for drinking in categories from unsuitable to poor.

The areas that suffer severely from the deterioration of groundwater and its unsuitability for drinking are Akhmim city, Al-Kawser city, and El-Kola area. Field investigations were conducted to confirm the reasons of groundwater unsuitability for drinking in these areas. These reasons are using septic tanks (sewage rooms) and injection wells to get rid of sewage in most of the study area, discharging liquid industrial wastes into the ground without proper treatment in Al- Kawser city, and using of treated wastewater in agriculture east of El-Kola area in a random and unplanned manner.

To use groundwater for drinking, the following recommendations should be taken into account:

- Treating groundwater before drinking so that water quality will fall within acceptable standard limits.

- Establishing sewerage networks in all residential areas, especially rural areas to prevent the seepage of wastewater to groundwater

- Forcing factories to treat their wastewater to be within the standard limits for liquid waste before discharging it
- Introducing restrictions on the use of untreated or partially treated sewage water for irrigation

Acknowledgements The authors express their gratitude to the National Authority for Remote Sensing and Space Sciences (NARSS) and for funding the field work and laboratory analysis. They also express their appreciation for late Prof. Ahmed El-Kammar, Professor of Geochemistry, Faculty of Science, Cairo University, and late Prof. Abdalla Mohammed Faid, Professor of Hydrogeology, NARSS, for supervising this work that is part of a master thesis 1 .

Funding Open access funding provided by The Science, Technology \& Innovation Funding Authority (STDF) in cooperation with The Egyptian Knowledge Bank (EKB).

\section{Declarations}

Conflict of interest The authors declare no competing interests.

Open Access This article is licensed under a Creative Commons Attribution 4.0 International License, which permits use, sharing, adaptation, distribution and reproduction in any medium or format, as long as you give appropriate credit to the original author(s) and the source, provide a link to the Creative Commons licence, and indicate if changes were made. The images or other third party material in this article are included in the article's Creative Commons licence, unless indicated otherwise in a credit line to the material. If material is not included in the article's Creative Commons licence and your intended use is not permitted by statutory regulation or exceeds the permitted use, you will need to obtain permission directly from the copyright holder. To view a copy of this licence, visit http://creativecommons.org/licenses/by/4.0/.

\section{References}

Abdel Moneim AA (1999) Geoelectrical and hydrogeological investigations of the groundwater resources on the area to the west of the cultivated land at Sohag Upper Egypt Egyptian. J Geol 43(2):253-268

Ahmed AA (2007) Using lithologic modeling techniques for aquifer characterization and groundwater flow modeling of the Sohag area, Egypt. Hydrogeol J 17(5):1189-1201. https://doi.org/10. 1007/s10040-009-0461-z

Ahmed AA (2009) Using generic and pesticide DRASTIC GIS-based models for vulnerability assessment of the Quaternary aquifer at Sohag Egypt. Hydrogeol J 17:1203-1217. https://doi.org/10.1007/ s10040-009-0433-3

Ahmed AA, Ali MH (2011) Hydrochemical evolution and variation of groundwater and its environmental impact at Sohag Egypt. Arab J Geosci 4(3):339-352. https://doi.org/10.1007/s12517-009-0055-z

Ahmed S, Khurshid S, Sultan W, Shadab MB (2020) Statistical analysis and water quality index development using GIS of Mathura City, Uttar Pradesh, India. Desalin Water Treat 177:152-166. https:// doi.org/10.5004/dwt.2020.24946

Ali MH, Mustafa ARA, El-Sheikh AA (2016) Geochemistry and spatial distribution of selected heavy metals in surface soil of Sohag, Egypt: a multivariate statistical and GIS approach. Environ Earth Sci $75: 1257$ 
Ali AM (2005) Evaluation of the Nile Valley aquifer from Aswan to Assiut using geographical and hydrogeological methods. D. Geol. Dept., Fac. Sci., South Valley University, Aswan, Egypt, Ph

Allam AR (1998) Artificial groundwater recharge in Egypt. Ph.D. Thesis. Egypt: Irrigation and Hydraulic Department, Faculty of Engineering, Cairo University

Ambiga K, Durai RA (2013) Use of geographical information system and water quality index to assess groundwater quality in and around Ranipet area, Vellore District, Tamil Nadu. Int J Adv Eng Res Stud 1:73-80

Anbazhagan S, Jothibasu A (2014) Modeling water quality index to assess groundwater quality for sustainable utilization in southern India. Int J Adv Geosciences 2(2):122-129. https://doi.org/ 10.14419/ijag.v2i2.3285

Balogun II, Akoteyon IS, Adeaga O (2012) Evaluating land use effects on groundwater quality in Lagos-Nigeria using water quality index. J Sci Res 4(2):397-409

Bharti N, Katyal D (2011) Water quality indices used for surface water vulnerability assessment. Int J Environ Sci 2:154-173

Brown RM, Mc Cleiland NJ, Deiniger RA ,O'Connor MF (1972) Water quality index -crossing the physical barrier. Intl Conf Water Poll Res Jerusalem 787-797

Brown RM, McClelland NI, Deininger RA, Tozer RG (1970) Water quality index-do we dare? Water Sewage Works 117(10):339-343

Chabuk A, Al-Madhlom Q, Al-Maliki A, Al-Ansari N, Hussain HM, Laue J (2020) Water quality assessment along Tigris River (Iraq) using water quality index (WQI) and GIS software. Arab J Geosci 13:654. https://doi.org/10.1007/s12517-020-05575-5

Chandra S, Asadi SS, Raju MV (2017) Estimation of water quality index by weighted arithmetic water quality index method: a model study. Int J Civ Eng Technol (IJCIET) 8(4):1215-1222

Chauhan A, Singh S (2010) Evaluation of Ganga water for drinking purpose by water quality index at Rishikesh, Uttarakhand India. Rep Opin 2(9):53-61

Chowdhury R, Muntasir S, Hossain M (2012) Water quality index of water bodies along Faridpur-Barisal road in Bangladesh. Glob Eng Tech Rev 2(3):1-8

Egyptian Ministry of Environment (2019) Retrieved from the official website of the Egyptian Ministry of Environment. www.eeaa.gov.eg

EEAA (Egyptian Environmental Affairs Agency) (1997) Sohag Governorate Environmental Profile, SEAM Programme, GEAPs/Health Care Waste/Industry/Municipal Solid Waste

EGSMA (1983) Geologic map of Egypt (1:250000)The Egyptian Geological Survey and Mining Authority

El Arabi N (2012) Environmental management of groundwater in Egypt via artificial recharge extending the practice to soil aquifer treatment (SAT). Int J Environ Sustainab 1(3):66-82

El-Gohary FA, Wahaab RA, Nasr FA, Ali HI (2002) Three Egyptian industrial wastewater management programmes. The Environ 22:59-65

EMH (2007) Ministerial decree (\# 458/2007) on guidelines for drinking water quality and the water quality for household uses. Egyptian Ministry of Health, Cairo

El Zeiny AM, Elbeih SF (2019) GIS based evaluation of groundwater quality and suitability in Dakhla. Earth Systems and Environment 3(3):507-523

Elbeih SF, Madani AA, Hagage M (2021) Groundwater deterioration in Akhmim District, Upper Egypt: a remote sensing and GIS investigation Aapproach. The Egyptian Journal of Remote Sensing and Space Sciences 24(3):919-932. https://doi.org/10.1016/j. ejrs.2021.10.002
Ewaid SH, Abed SA (2017) Water quality index for Al-Gharraf River, southern Iraq. Egypt J Aquat Res 43(2):117-122. https://doi. org/10.1016\%2Fj.ejar.2017.03.001

FAO (2003) Users manual for irrigation with treated wastewater. Cairo: FAO Regional Office for the Near East. http://www.fao.org/3/ y5009e/y5009e00.htm

Hagage M (2021) Impacts of anthropogenic activities on the deterioration of groundwater and archaeological sites in Akhmim area, Sohag Governorate, Egypt: remote sensing and GIS applications. M.Sc. Thesis. Cairo University, Faculty of Science, Egypt

Horton RK (1965) An index number system for rating water quality. J Walter Poll Cont Fed 37(3):300-306

Howladar MF, Al NumanbakthM A, Faruque MO (2017) An application of water quality index(WQI) and multivariate statistics to evaluatethe water quality around Maddhapara Granite Mining Industrial Area, Dinajpur, Bangladesh. Environ Syst Res 1:6-13

Lu G, Wong D (2008) An adaptive inverse-distance weighting spatial interpolation technique. Comput Geosci 34(9):1044-1055. https:// doi.org/10.1016/j.cageo.2007.07.010

Madhloom HM, Alansari N (2018) Geographical information system and remote sensing for water resources management case study: the Diyala River, Iraq. Int J Civil Eng Technol 9(12): 971-984. http://orcid.org/0000-0002-6790-2653

Magesh NS, Krishnakumar S, Chandrasekar N, Soundranayagam JP (2013) Groundwater quality assessment using WQI and GIS techniques, Dindigul district, Tamil Nadu. India. Arab J Geosci 6(11):4179-4189. https://doi.org/10.1007\%2Fs12517-012-0673-8

Massoud M (2012) Assessment of water quality along a recreational section of the Damour River in Lebanon using the water quality index. Environ Monit Assess 184(7):4151-4160. https://doi. org/10.1007/s10661-011-2251-z

Nasirian M (2007) A new water quality index for environmental contamination contributed by mineral processing: a case study of Amang (tin tailing) processing activity. J Appli Sci 7(20):2977_ 2987. https://doi.org/10.3923/jas.2007.2977.2987

Negm AM, Armanuos AM (2016) GIS-based spatial distribution of groundwater quality in the western Nile Delta, Egypt. In The Handbook of Environmental Chemistry; Springer: Cham, Germany, 2016

Omer AA, Youssef AM,Ibrahim MS, Ali MH( 2005) Investigation of the sewage wastewater disposal sites and assessment of their environmental hazards, Sohag, Upper Egypt. 16th Symposium on Quaternary Geology and Development in Egypt, Mansoura, April 2nd, 2005 (Abstract)

Rokbani MK, Gueddar M, Bouhlila R (2011) Use of geographical information system and water quality index to assess groundwater quality in El Khairat deep aquifer (Enfidha, Tunisian Sahel). Iranica J Energy Environ 2(2):133-144. http://www.ijee.net/artic le_64339.html

SAFE (1995) Strategic assessment of Florida's environment indicators. Florida stream water quality index (WQI). Retrieved from http:// www.pepps.fsu.edu/safe/pdf/swq3.pdf

Sayed E, Riad P, Elbeih S, Hassan A, Hagras M (2020) Sustainable groundwater management in arid regions considering climate change impacts in Moghra region, Egypt. Groundwater Sustainab Dev 11:100385

Simeonov V, Einax J, Stanimirova I, Kraft J (2002) Environmetric modeling and interpretation of river water monitoring data. Anal Bioanal Chem 374:898-905. https://doi.org/10.1007/ s00216-002-1559-5

Smith DG (1989) A new form of water quality index for rivers and streams. Water Sci Technol 21(2):123-127 
Sharma PK, Vijay R, Punia MP (2016) Groundwater quality assessment using water quality index and GIS in Rajasthan, India. Int J Adv Remote Sens GIS Geogr 4(2):12-26

Singh DF (1992) Studies on the water quality index of some major rivers of Pune Maharashtra. Proc Acad Environ Biol 1:61-66

Tiwari AK, Singh AK, Mahato MK (2018) Assessment of groundwater quality of Pratapgarh district in India for suitability of drinking purpose using water quality index (WQI) and GIS technique. Sustain Water Resour Manag 4:601-616

Tyagi S, Sharma B, Singh P, Dobhal R (2013) Water quality assessment in terms of water quality index. Am J Water Resourc 1(3):34-38. https://doi.org/10.12691/ajwr-1-3-3

Vaiphei SP, Kurakalva RM, Sahadevan DK (2020) Water quality index and GIS-based technique for assessment of groundwater quality in Wanaparthy watershed, Telangana, India. Environ Sci Pollut Res 27:45041-45062
WHO (2011) Guidelines for drinking-water quality (4th ed., Vol. 564). Geneva: World Health Organization

Yao S, Xue B, Kong D (2010) Chronology and nutrients change in recent sediment of Taihu Lake, lower Changjiang River Basin, East China. Chin Geogr Sci 20:202-208. https://doi.org/10.1007/ s11769-010-0202-1

Youssef AM, Omer AA, Ibrahim MS, Ali MH, Cawlfield JD (2011) Geotechnical investigation of sewage wastewater disposal sites and use of GIS land use maps to assess environmental hazards: Sohag Upper Egypt. Arab J Geosci 4(5-6):719-733. https://doi. org/10.1007/s12517-009-0069-6

Youssef AM, Abdel Moneim AA (2006) Evaluation of the geoenvironmental hazard in relation to the future development using geographic information system, East Sohag area , Egypt.The 3rd. Int. Conf. for Develop. and the Env. in the Arab world, March, 21-23. Assiut University Center for Environmental Studies-Egypt 